\title{
Mucinous cystadenoma and cystadenocarcinoma of the vermiform appendix with particular reference to mucocele and pseudomyxoma peritonei
}

\author{
N. M. GIBBS \\ From the Area Laboratory, St Luke's Hospital, Guildford, and the Research Department, \\ St Mark's Hospital, London
}

SYNOPSIS Ten cases of mucocele of the vermiform appendix are described. Eight cases were of mucinous cystadenoma of the appendix and six cases showed acute inflammation. Two of the six cases showed pseudoinvasion of the appendix and in a further case the appendix had perforated with extrusion of a misplaced neoplasm. Two cases were of mucinous cystadenocarcinoma and one of these was diagnosed as 'pseudomyxoma peritonei'. 'Pseudomyxoma peritonei' is a misnomer and is caused by dissemination of a mucinous cystadenocarcinoma within the peritoneal cavity. The special problems of histological diagnosis are discussed.

Mucocele of the appendix is an uncommon but mysterious condition about which a large volume of literature has accumulated without much clarification of the underlying pathology. There are two main theories of causation. The first can be termed the 'obstructive' theory because it is thought that the distal mucosa of the appendix is stimulated to produce an excessive secretion of mucin, as a result of proximal obstruction of the lumen by faeces, inflammatory fibrosis, or the presence of a neoplasm (Elliott, 1957). The second theory, which is an extension of the first, asserts that the mucosa of the obstructed appendix undergoes an ill defined neoplastic change which has been termed 'adenocarcinoma grade I' (Woodruff and McDonald, 1940 ) or papillary mucus-secreting carcinoma in situ (Scimeca and Dockerty, 1955).

The mystery deepens when 'pseudomyxoma peritonei', which is a complication of mucocele of the appendix, is considered. The original hypothesis (Werth, 1884) postulates that peritoneal irritation, produced by the leakage of mucus from a burst mucocele, causes a metaplastic reaction to take place in the mesothelial cells so that mucin is formed locally in the peritoneal cavity. Other hypotheses accept that malignant adenocarcinomas of the appendix can produce pseudomyxoma peritonei, but there is also the opinion that it may occur in the Received for publication 5 April 1973. presence of a neoplasm which is not invasive or where there is an abnormal epithelium which is not neoplastic.

The object of this paper is to describe the histology of 10 appendices and to consider the underlying pathology with particular relation to mucocele and pseudomyxoma peritonei.

\section{Materials and Methods}

The appendices were fixed in $10 \%$ formal saline. Coronal blocks in sequence were taken so that the entire appendix was examined in each case with the exception of cases 3,6 , and 10 . Sections were cut at $5 \mu$ and stained routinely by Ehrlich's acid haematoxylin and counterstained with eosin. Special stains included phloxine tartrazine for Paneth cells, the diazo method, and Fontana's silver impregnation for enterochromaffin granules, alcian blue, and PAS (pH 2.6) for mucin.

The cases are summarized in table $I$.

\section{Histology}

The histological details of cases 1-10 are given in table II.

Cases 1-8 showed a replacement of the lining epithelium of the surface and the glands by tall columnar mucinous epithelium which characteris413 


\begin{tabular}{|c|c|c|c|c|c|}
\hline Case No. & Date & $\operatorname{Sex}$ & $\begin{array}{l}\text { Age in } \\
\text { Years }\end{array}$ & Clinical History & Follow Up \\
\hline 1 & March 1972 & $q$ & 76 & $\begin{array}{l}\text { Incidental finding at necropsy for basilar arterial } \\
\text { thrombosis }\end{array}$ & \\
\hline 2 & March 1971 & ㅇ & 59 & $\begin{array}{l}\text { Presented with acute abdominal pain, and laparotomy } \\
\text { revealed perforated diverticulum of the caecum and a } \\
\text { mucocele of the appendix. The appendix was removed. }\end{array}$ & Complete recovery \\
\hline 3 & November 1957 & a & 54 & $\begin{array}{l}\text { Presented with acute abdominal pain and } \\
\text { appendicectomy was done followed by an interval } \\
\text { right hemicolectomy. }\end{array}$ & Complete recovery \\
\hline 4 & June 1972 & $\sigma$ & 47 & $\begin{array}{l}\text { Acute abdominal pain followed by appendix mass for } \\
\text { six weeks, and appendicectomy }\end{array}$ & Complete recovery \\
\hline 5 & September 1972 & శै & 37 & $\begin{array}{l}\text { Acute appendicitis and appendix mass followed by } \\
\text { 'interval' appendicectomy three months later }\end{array}$ & Complete recovery \\
\hline 6 & January 1957 & q & 70 & $\begin{array}{l}\text { Acute appendicitis associated with localized abscess } \\
\text { filled with mucoid pus }\end{array}$ & $\begin{array}{l}\text { Alive and well when } \\
\text { last seen in } 1963\end{array}$ \\
\hline 7 & March 1972 & 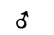 & 70 & Acute appendicitis and appendicectomy & Complete recovery \\
\hline 8 & October 1972 & $q$ & 71 & $\begin{array}{l}\text { Abdominal pain followed by a mass in the abdomen } \\
\text { for four months; this was explored and an inflamed } \\
\text { perforated distended appendix was removed. }\end{array}$ & Complete recovery \\
\hline 9 & June 1965 & $\sigma$ & 54 & $\begin{array}{l}\text { Two-day history of abdominal pain and distension; } \\
\text { an appendicectomy was done. A right hemicolectomy } \\
\text { was done six weeks later }\end{array}$ & Complete recovery \\
\hline 10 & May 1971 & $\sigma$ & 45 & $\begin{array}{l}\text { There was abdominal pain and swelling for two } \\
\text { months; an abscess in the lower abdomen was in- } \\
\text { cised and drained in May } 1971 \text {. This recurred and much } \\
\text { mucus was evacuated. A diagnosis of pseudomyxoma } \\
\text { peritonei was made and a right hemicolectomy was } \\
\text { done. Further accumulation of mucin occurred and } \\
\text { a metastasis in the abdominal wall was biopsied in } \\
\text { June } 1972 \text {. }\end{array}$ & $\begin{array}{l}\text { Disseminated intra- } \\
\text { abdominal adeno- } \\
\text { carcinoma }\end{array}$ \\
\hline
\end{tabular}

Table I Clinical details of cases 1 to 10

tically showed basal crowding of nuclei and the presence of numerous mitoses. The epithelium looked neoplastic, and villous processes were developed in some cases (cases 4 and 5) with an appearance identical to the villous adenomas of the large intestine. In addition the glands were tortuous and showed lateral branching and budding of cystic tubules (figs 1, 2, and 3). There were numerous mitoses and the basi-glandular cells of the crypts tended to be displaced by mucinous epithelium. Thus the Paneth cells disappeared and argentaffin cells were diminished and displaced, a common factor in neoplasms of the intestine which distinguishes them from hyperplasias and heterotopias (Gibbs, 1967). Polypoid mucosal hyperplasia (metaplasia) may occur in the appendix (MacGillivray, 1972) but the epithelium, although tall, only shows occasional goblet cells whilst the surface epithelial cells have a veiled or fronded appearance.

Cases 1 and 2 showed 'sac-like' dilatations (mucoceles) and here there was widespread pressure atrophy of the lining epithelium (fig 4) and partial replacement by granulation tissue with a 'foreignbody' giant cell reaction. The glands were stretched by accumulated mucin and many had disappeared. Nevertheless the characteristic neoplastic epithelium was preserved in occasional cul de sacs. It would seem that further development of the tumours was impeded by mucus retention.

Cases 1, 2, 4, and 5 showed partial or complete organic obstruction of the proximal lumen by fibrous tissue which had replaced or constricted the epithelial lining. It is possible that obstruction was due to congenital absence of part of the mucosa or possibly to an episode of localized proximal inflammation. It seems more likely, however, that the viscid mucin secreted by the tumour was unable to drain into the caecum so that the adjacent normal mucosa underwent pressure atrophy. The thickened tumour mucosa may have blocked the proximal lumen but in either event the normal mucosa will be subject to compression and inflammation with eventual atrophy and reactive fibrosis as sequelae. Alternatively blockage could result from calcified inspissated mucus (case 5, fig 5). It seems that if free drainage of mucin from the tumour were possible a sacular dilatation (mucocele) of the appendix would not develop.

Cases 3, 4, and 5 did not show diffuse dilatation of the appendices but instead developed diverticula These diverticula bulged through and between the muscle coats and formed lakes of mucus lined in part by mucinous epithelium. Acute inflammation had occurred with consequent perforation and 


\begin{tabular}{|c|c|c|}
\hline $\begin{array}{l}\text { Case } \\
\text { No. }\end{array}$ & $\begin{array}{l}\text { Macroscopic } \\
\text { Description }\end{array}$ & Lumen \\
\hline 1 & $\begin{array}{l}\text { Appendix }(6 \times 2 \\
\mathrm{cm}) \text { showed gross } \\
\text { distension of distal } \\
\text { half by mucus. }\end{array}$ & $\begin{array}{l}\text { Proximal half of } \\
\text { lumen showed } \\
\text { fibrous obliteratio }\end{array}$ \\
\hline 2 & $\begin{array}{l}\text { Appendix }(6 \times 1.5 \\
\mathrm{cm}) \text { showed gross } \\
\text { distension of distal } \\
\text { part by mucus. }\end{array}$ & $\begin{array}{l}\text { Proximal lumen } \\
\text { showed fibrous } \\
\text { obliteration. }\end{array}$ \\
\hline 3 & $\begin{array}{l}\text { Appendix showed } \\
\text { distension of the } \\
\text { middle part by } \\
\text { mucin and pus. }\end{array}$ & \\
\hline 4 & $\begin{array}{l}\text { Appendix }(4 \times 0.8 \\
\mathrm{cm}) \text { showed distal } \\
\text { dilatation }(1.5 \times 1 \\
\mathrm{cm}) \text { and globules } \\
\text { of mucin could be } \\
\text { seen beneath the } \\
\text { peritoneal coat. }\end{array}$ & $\begin{array}{l}\text { Proximal lumen } \\
\text { showed fibrous } \\
\text { obliteration. }\end{array}$ \\
\hline 5 & $\begin{array}{l}\text { Appendix }(5 \times 2 \\
\mathrm{cm}) \text { showed distal } \\
\text { dilatation and was } \\
\text { filled with mucin } \\
\text { and pus. There was } \\
\text { an old perforation } \\
\text { with adhesion to the } \\
\text { caecum and a } \\
\text { deposit of jelly-like } \\
\text { mucin. }\end{array}$ & $\begin{array}{l}\text { Proximal lumen } \\
\text { obliterated by } \\
\text { fibrous tissue; } \\
\text { distal lumen } \\
\text { contained a } \\
\text { calculus } \\
\text { e }\end{array}$ \\
\hline 6 & $\begin{array}{l}\text { Appendix was } \\
\text { distended with pus } \\
\text { and mucus and } \\
\text { there was a perfora- } \\
\text { tion and abscess. }\end{array}$ & \\
\hline 7 & $\begin{array}{l}\text { Appendix distended } \\
\text { by pus and mucin; } \\
\text { adherent to caecum } \\
\text { which showed } \\
\text { gangrenous necrosis. }\end{array}$ & \\
\hline 8 & $\begin{array}{l}\text { Appendix was } \\
\text { distended with pus } \\
\text { and mucus and was } \\
\text { perforated. }\end{array}$ & \\
\hline
\end{tabular}

$9 \quad$ Appendix $(6 \times 3$ Patent $\mathrm{cm})$ was sealed with omentum and had not perforated. The distal threequarters of the appendix were distended by mucin and the wall was thickened.

10 Appendix was fragmented and involved by a

tumour mass and an abscess.

$\begin{array}{ll}\text { Microscopic Description } & \begin{array}{l}\text { Appendix } \\ \text { Diverticulum }\end{array}\end{array}$

Absent

columnar mucinous epithelium which was

. stretched and flattened. Most of the crypts had disappeared.

The distal mucosa was replaced by tall columnar mucinous epithelium. The gland crypts had disappeared.

The mucosa of the dilated part was replaced by tall columnar mucinous epithelium which showed areas of flattening and inflammation.

The distal mucosa was replaced by tall columnar mucinous epithelium showing branched papillary processes, but foci of atrophy and inflammation were present.

The distal mucosa was replaced by tall mucinous columnar epithelium which formed papillary processes projecting into the lumen. The glands were elongated and showed pronounced lateral branching and mitotic activity.

Absent

Present

No residual growth found in caecum and ascending colon

Present

Rupture of diverticulum into the interstitial tissues of the appendix and 'displacement' of fragmented mucosa

No extension of growth into caecum; lymph glands in appendix mesentery did not contain metastases.

The distal mucosa was replaced by disrupted tall columnar mucinous epithelium. There was diffuse acute purulent inflammation.

Acute purulent inflammation of the appendix; crypts were replaced by atypical tall columnar mucinous epithelium which showed a surface villous pattern and tortuous glands.

There was marked inflammatory thickening and the mucosa was replaced by tall mucinous columnar epithelium. There were surface villous processes and hyperplastic glands although in places the epithelium was stretched and attenuated.

The proximal glands were normal but the remainder were hyperplastic and replaced by tall columnar mucin-secreting epithelium. The distal half was infiltrated by mucinous adenocarcinoma showing a large glandular pattern; 'signet-ring' cells were present; numerous argentaffin cells in both large tubules and 'signet-ring' cells.

There was a primary mucinous adenocarcinoma of the appendix with a complex acinar pattern, and surrounded by 'lakes' of mucin. Argentaffin cells were not

Absent seen.

Diffuse invasion of the peritoneum; no diverticulum
An interval right hemicolectomy was done and the ileocaecal lymph glands contained metastases.

Interval right hemicolectomy showed carcinoma of the appendix invading the caecum; developed metastases in abdominal wall. 

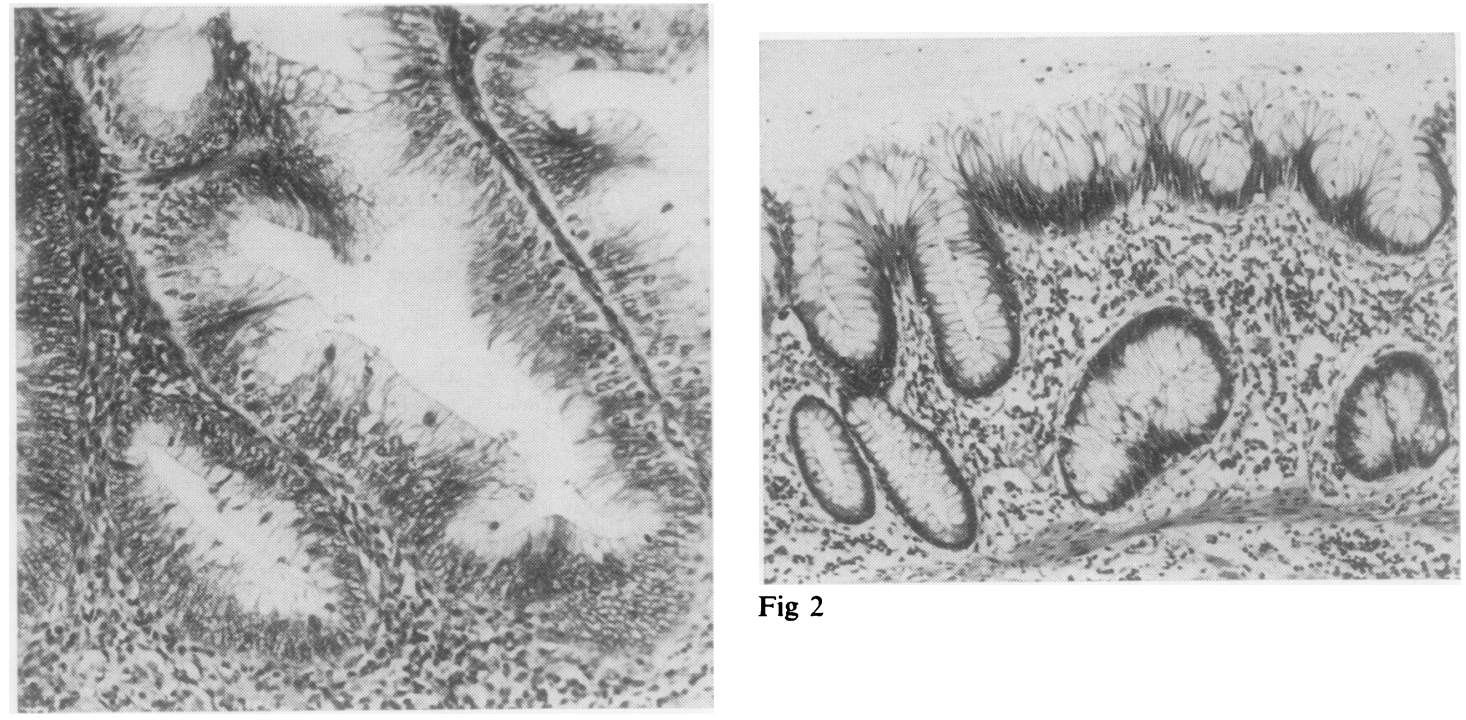

Fig 2

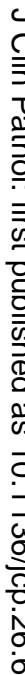

Fig 1

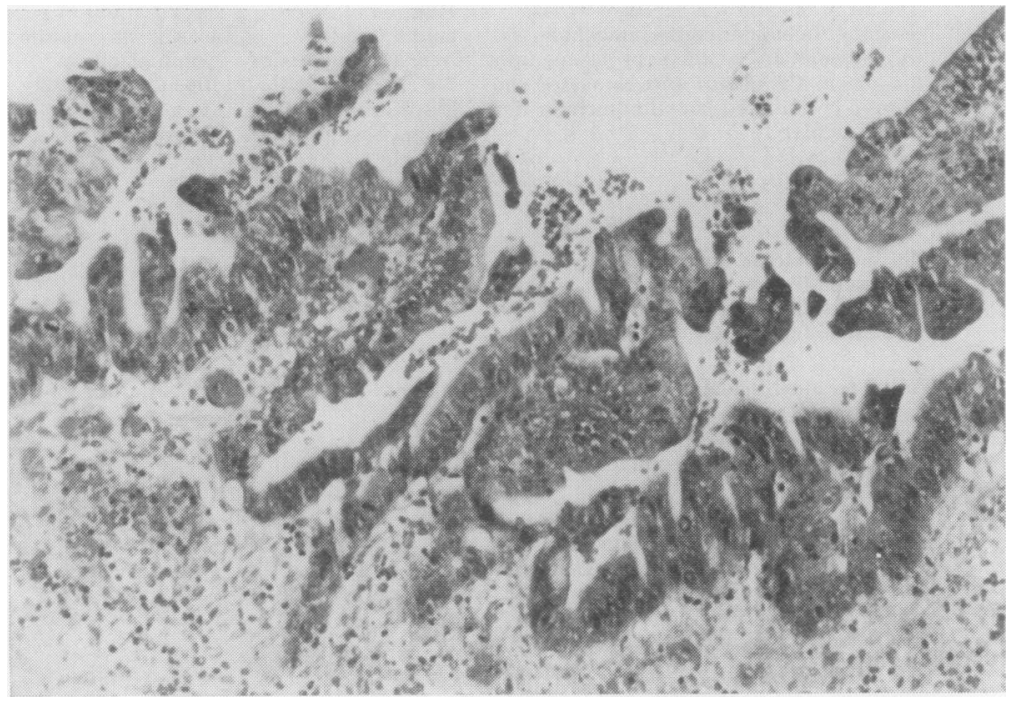

Fig 3

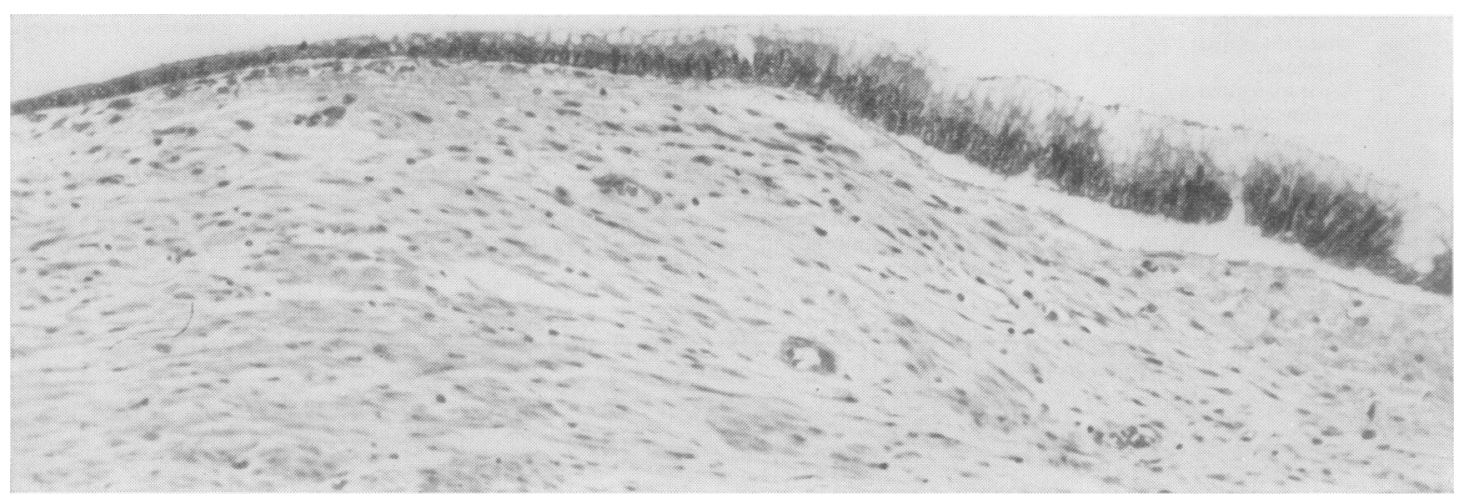

Fig 4 


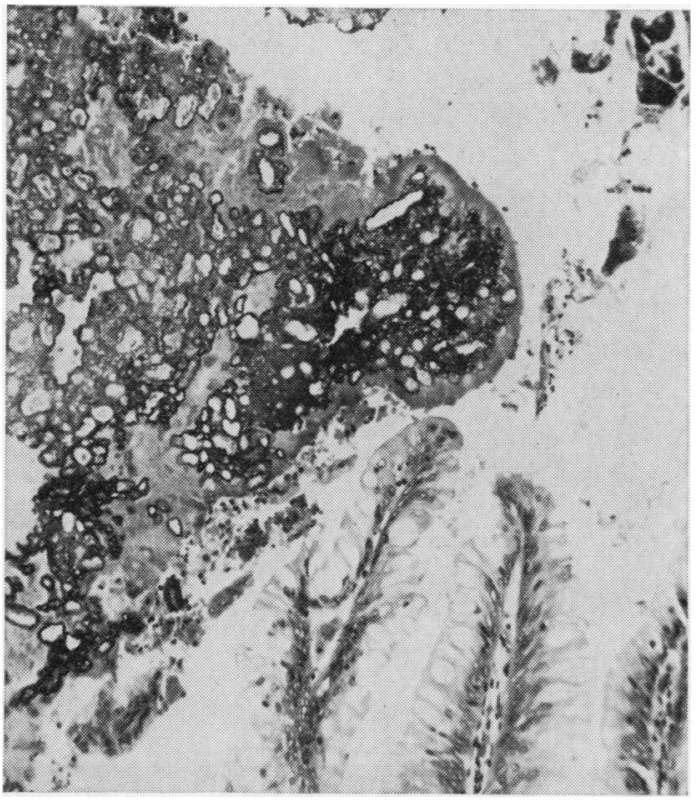

Fig 5

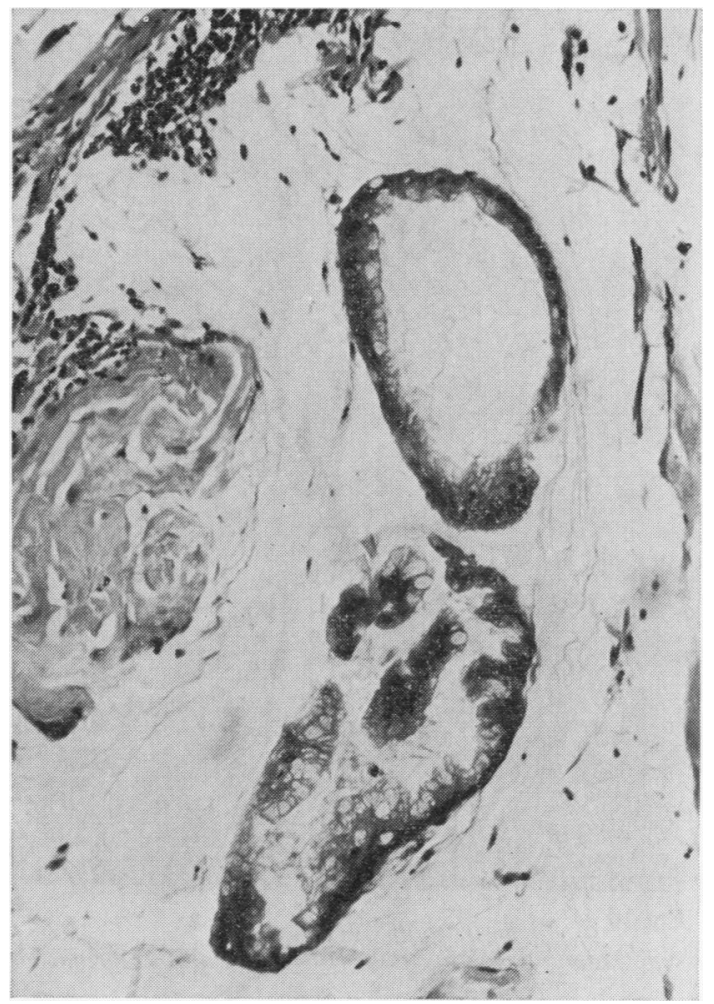

Fig 6

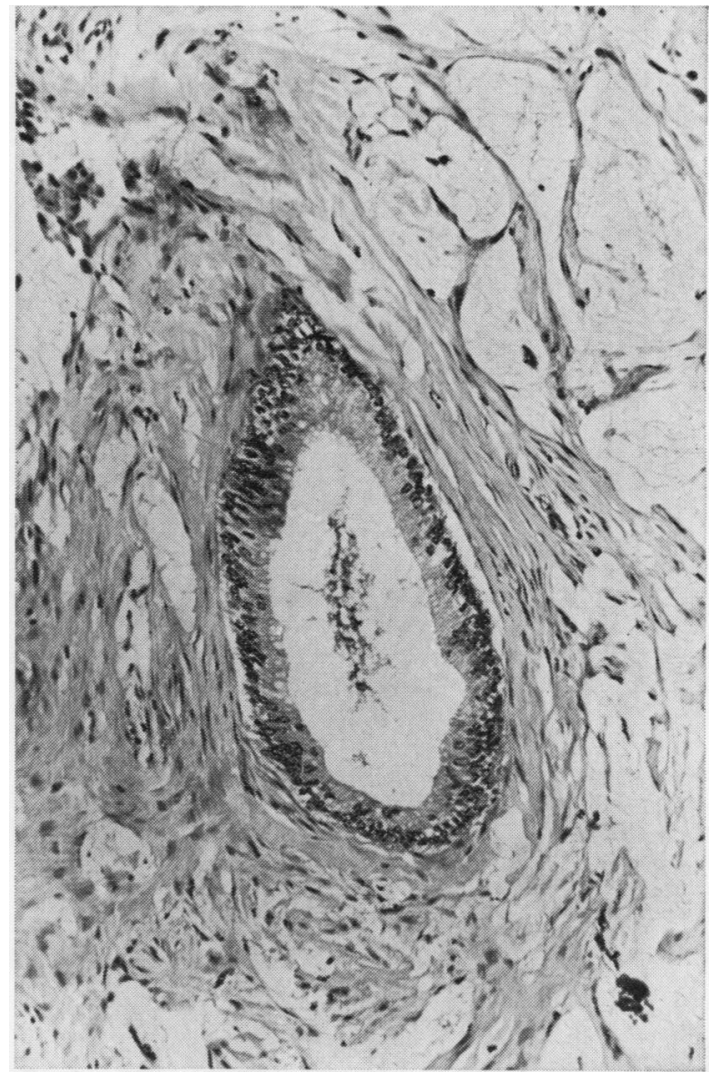

Fig 7

Fig 1 Case 5: mucinous cystadenoma of the appendix lined by tall columnar mucinous epithelium (haematoxylin and eosin $\times 100$ ).

Fig 2 Case 4: mucinous cystadenoma of the appendix showing replacement of surface and glandular epithelium by tall mucinous epithelium (haematoxylin and eosin $\times 80)$.

Fig 3 Case 3: inflamed mucocele showing distorted villous epithelium (haematoxylin and eosin $\times 63$ ).

Fig 4 Case 1: mucocele of the appendix showing progressive flattening of the lining epithelium (haematoxylin and eosin $\times 63$ ).

Fig 5 Case 5: mucinous cystadenoma of appendix showing villous processes and calcified secretion (calculus) (haematoxylin and eosin $\times 63$ ).

Fig 6 Case 5: epithelial displacement and pseudoinvasion in a perforated mucocele of appendix (haematoxylin and eosin $\times 63$ ).

Fig 7 Case 5: epithelial displacement and pseudoinvasion in a perforated mucocele of appendix (haematoxylin and eosin $\times 100$ ). 


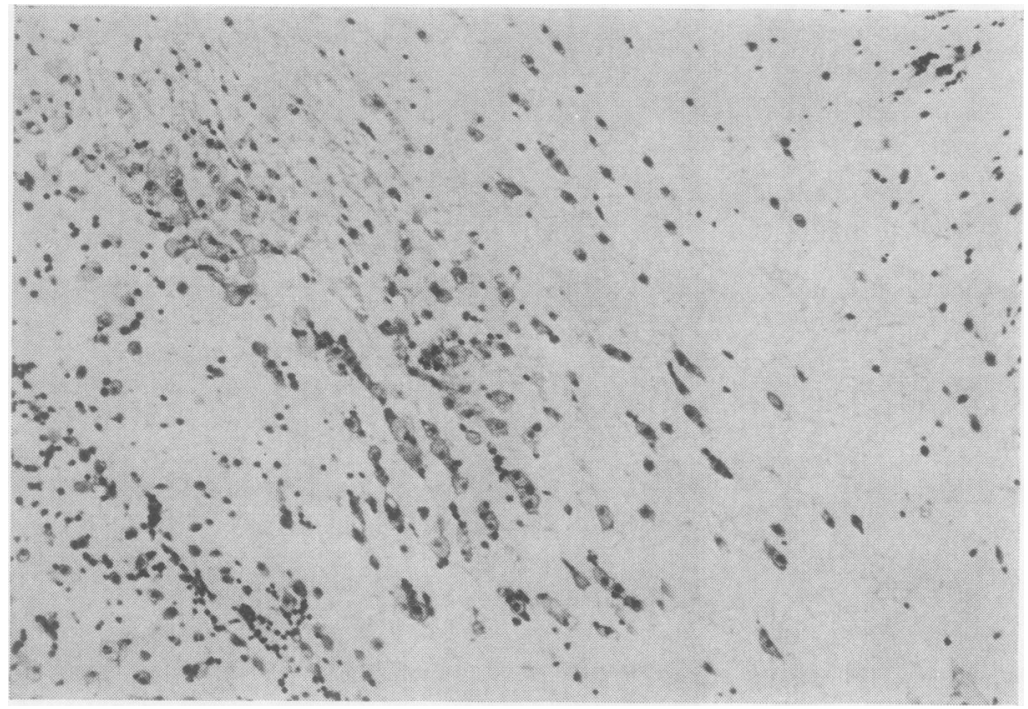

Fig 8 Case 4: interstitial mucin showing muciphages (haematoxylin and eosin $\times 80$ ).

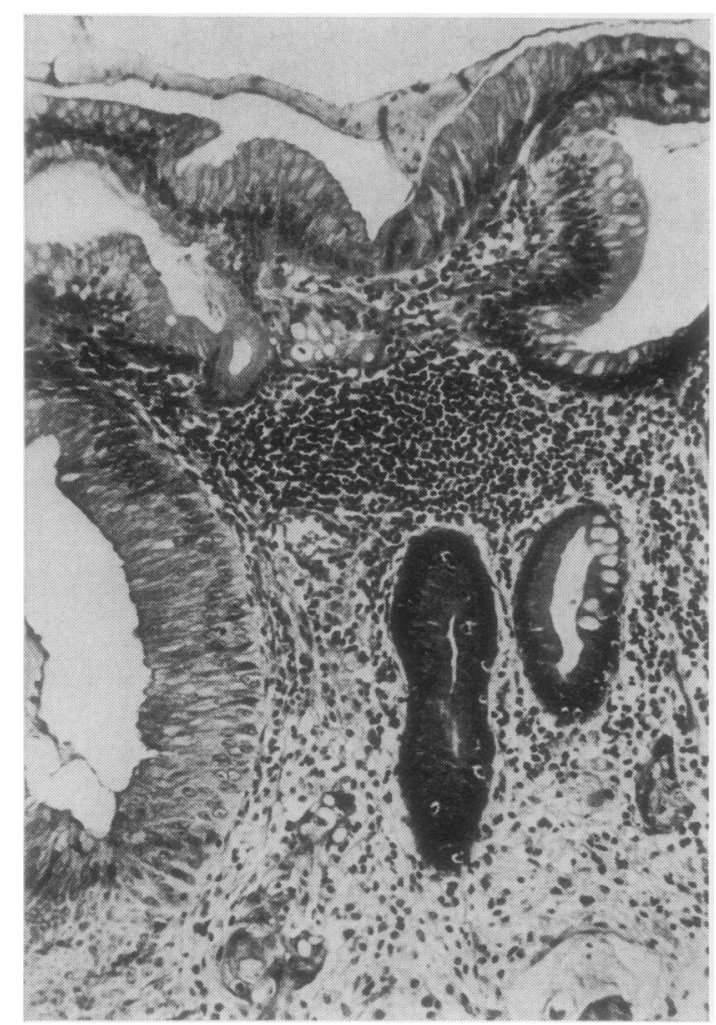

Fig 9

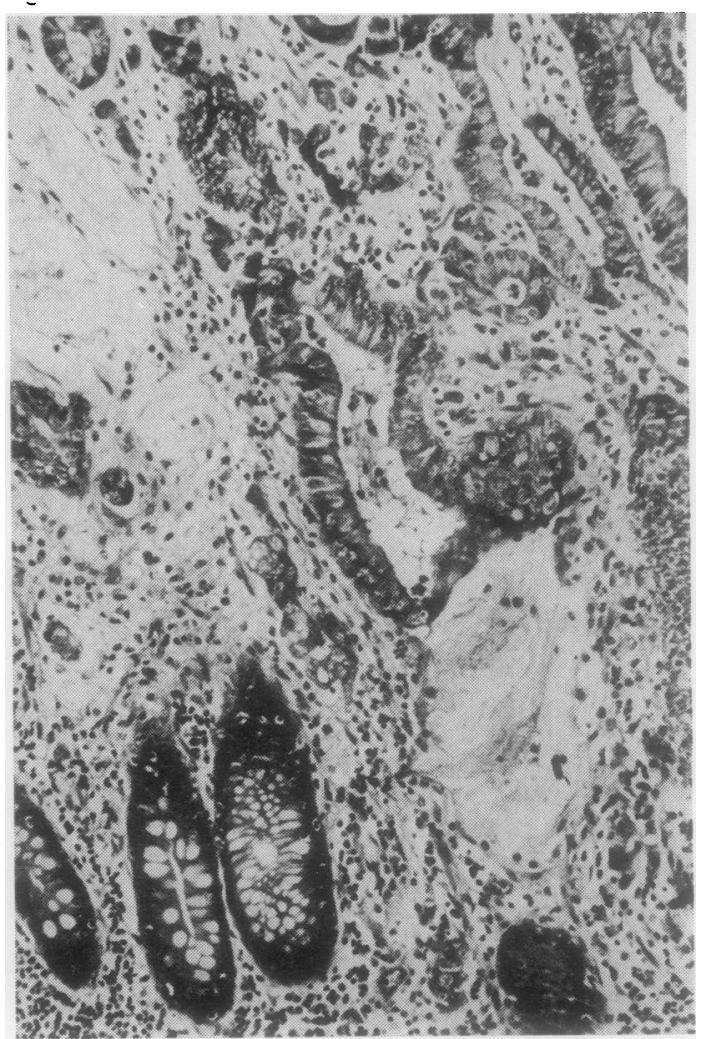

Fig 10

Fig 9 Case 9: mucinous cystadenocarcinoma of appendix showing junction with normal epithelium and the formation of surface villous processes (haematoxylin and eosin $\times 100$ ).

Fig 10 Case 9: mucinous cystadenocarcinoma of appendix (haematoxylin and eosin $\times 100$ ). 


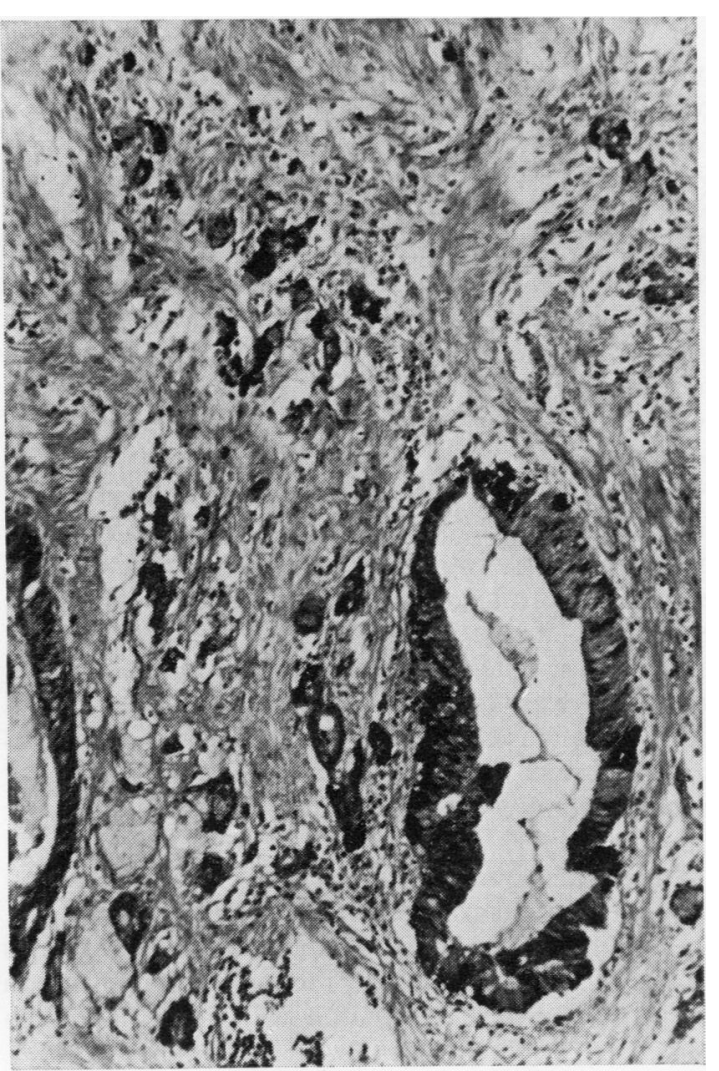

Fig 11

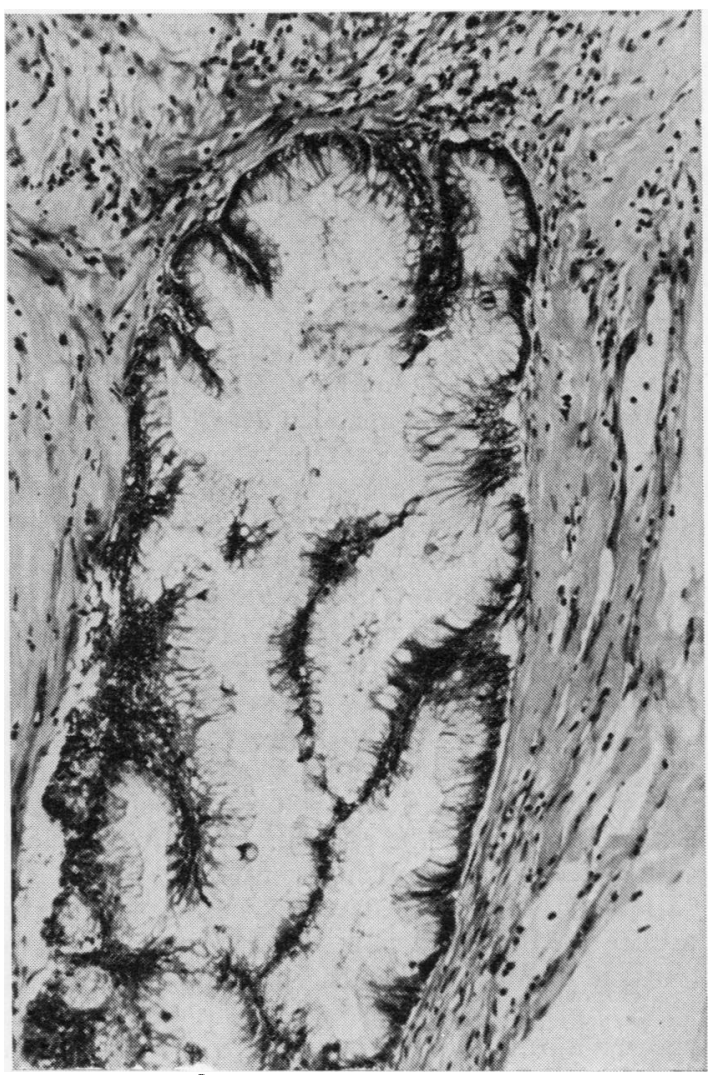

Fig 12

Fig 11 Case 9: mucinous cystadenocarcinoma of appendix showing numerous argentaffin cells (Fontana's silver counterstained with saffranin, $\times 100)$.

Fig 12 Case 10: mucinous cystadenocarcinoma of appendix with abdominal metastasis (haematoxylin and cosin $\times 63)$.

disruption of the lining epithelium. Strips of displaced epithelium could be seen lying interstitially producing a semblance of invasion (figs 6 and 7) and mucinous epithelium had grown through the perforation tracks in cases 4 and 5 . Large numbers of macrophages were present in the interstitial mucin and this complicated the histology (fig 8).

Cases 1-8 cover the histological 'spectrum' of an epithelial neoplasm of the appendix which is considered to be a primary mucinous cystadenoma. It can be seen that considerable variations in histology occur in these neoplasms which appear to be the result of local factors influencing tumour growth.

Case 9 was an invasive mucinous neoplasm of the appendix forming large numbers of argentaffin cells and was considered to be a primary mucinous cystadenocarcinoma of the appendix (figs 9, 10, and 11).
There was acute appendicitis wihout perforation so that peritoneal dissemination had not occurred although there were lymphatic metastases. Case 10 was a similar tumour but perforation and appendix abscess had occurred which was followed by disscmination of the mucinous cystadenocarcinoma within the peritoneal cavity and 'pseudomyxoma peritonei' (fig 12).

\section{Discussion}

Mucinous cystadenoma of the appendix is an uncommon tumour which secretes viscid mucus that tends to accumulate within the lumen so that it becomes distended to produce a mucocele. If the lumen proximal to the tumour is narrow, the mucus may not drain. However, four of the mucoceles described here are associated with severe narrowing 
or complete obstruction of their lumina which is probably related to abnormalities in development of the organ or subclinical episodes of acute inflammation. It is evident that epithelial displacement and pseudoinvasion are related to definite clinical episodes of acute appendicitis. In longstanding cases calcification of inspissated mucus (case 5) may result in the formation of an appendiceal calculus (Bunch, 1945) which may be detected radiographically (Marshak and Gerson, 1960).

Mucinous cystadenoma of the intestine is found, it seems, only in the appendix. However, it shares many of the morphological characteristics of villous adenoma of the colon and it can be argued that the tumours described are in fact villous adenomas which have been altered by the confines of the appendix. Nevertheless it is known that epithelial neoplasms of the appendix show significant differences from neoplasms elsewhere in the intestine. For example, the appendix is the most common site of carcinoid tumours which, in this situation, are almost always benign, often show mucin secretion, and may contain Paneth cells. Furthermore some primary adenocarcinomas of the appendix show histological features not found in other organs.

The cases of mucocele described in this paper show the characteristic epithelial abnormalities common to reports in the literature when a detailed examination of the appendix has been made. The nature of the abnormalities, however, has been fogged by much dubious and imprecise terminology. Many authors have been unable to decide whether the epithelial lesion is metaplastic or neoplastic, benign or malignant, and others diagnose carcinoma in situ, which is a concept best avoided in the consideration of neoplasms of the intestine. The reasons for the apparent contradictions seem to depend on special problems of interpretation. The neoplastic epithelium forming the mucocele may undergo deformation due to pressure of accumulated mucus so that the epithelium may become flattened or atrophic. Thus the neoplastic epithelium of the mucocele may pass unrecognized unless a detailed histological examination of the appendix is undertaken. Furthermore, the neoplastic cells of the mucocele, whether invasive or not, usually do not show cytological proof of malignancy, a finding in common with other neoplasms of the intestinal tract. The presence of large pools of mucin may distort local anatomy and when perforation takes place the epithelium may be displaced and extruded into the peritoneal cavity simulating invasion. A similar problem of interpretation is encountered in adenomatous polyps of the colon, which may show displacement of glandular tissue into the stalk. This displacement may be mistaken for malignant transformation and invasion.
It can be seen, therefore, that a distinction between benign and malignant mucinous cystadenoma may be a difficult problem. This provides an explanation for the observation made by Hilsabeck, Judd, and Woolner (1951) that the majority of cases diagnosed histologically as malignant failed to progress once the mucocele was removed and that only two of 18 patients with mucocele developed pseudomyxoma peritonei and died. The clinical diagnosis may also be problematic as a very large pseudocyst filled with mucin may form around a perforated mucocele which may be mistaken for 'pseudomyxoma peritonei' (Early, Stephenson, and Davis, 1968). However, the problem of interpretation is simplified if the histologist is aware of the possibility of pseudoinvasion by displaced islands of neoplastic epithelium in an area of inflammation. Conclusive evidence of tissue invasion must be found before a diagnosis of mucinous cystadenocarcinoma is made and this was readily available in the examples described (cases 9 and 10). Benign mucinous cystadenomas (mucoceles) should be treated by appendicectomy and more radical procedures are unnecessary.

Mucinous cystadenocarcinoma behaves as an invasive neoplasm (cases 9 and 10). Such tumours, in common with other mucinous adenocarcinomas of the intestinal tract, may produce by differentiation large numbers of argentaffin cells and have been mistaken for carcinoids (Evans and Murphy, 1959). A tumour which invades and disseminates within the peritoneal cavity after the appendix has been totally removed must be regarded by definition as malignant.

The alarming clinical features produced by dissemination of a mucinous carcinoma within the peritoneal cavity were described by Fraenkel (1901) in relation to mucocele of the appendix. He used the term 'pseudomyxoma peritonei', which had originally been given by Werth (1884) to describe a similar clinical picture associated with 'cystadenoma' of the ovary. Certainly pseudomyxoma peritonei is a misnomer with emotive connotations which even today causes histologists and clinicians to cast aside recognized precepts of disease. It should be left behind with the past.

I wish to thank Dr B. C. Morson and the surgeons of St Luke's Hospital, Guildford, St Peter's Hospital, Chertsey, and St Mark's Hospital, London, for permission to study their patients, and Dr G. F. Ross for pathological material of two cases.

\section{References}

Bunch, G. H. (1945). Mucoid disease of the appendix. Ann. Surg., 121. 704-709.

Early, K. S., Stephenson, D. V., Jr., and Davis, W. C. (1968). Giant 
retroperitoneal mucocele simulating pseudomyxoma peritonei and mucinous adenocarcinoma. Amer. J. Surg., 116, 439-443.

Elliott, C. E. (1957). Two cases of pseudomyxoma peritonei from mucocele of the appendix. Brit. J. Surg., 45, 15-18.

Evans, R. W., and Murphy, A. F. (1959). Pseudomyxoma peritonei associated with an appendix obstructed by an argentaffinoma (carcinoid) in a male. Brit. J. Surg., 47, 166-172.

Fraenkel, E. (1901). Uber das sogenannte pseudomyxoma peritonei. Münch. med. Wschr., 48, 965-970.

Gibbs, N. M. (1967). Incidence and significance of argentaffin and Paneth cells in some tumours of the large intestine. J. clin. Path., 20, 826-831.

Hilsabeck, J. R., Judd, E. S., Jr., and Woolner, L. B. (1951). Symposium on surgical aspects of cancer problem: carcinoma of the vermiform appendix. Surg. Clin. N. Amer., 31, 995-1011.

MacGillivray, J. B. (1972). Mucosal metaplasia in the appendix. $J$. clin. Path., 25, 809-811.

Marshak, R. H., and Gerson, A. (1960). Mucocele of the appendix. Amer. J. dig. Dis., 5, 49-54.

Scimeca, W. B., and Dockerty, M. B. (1955). Carcinoma of the vermiform appendix: a review of the literature and report of a case. Proc. Mayo Clin., 30, 527-534.

Werth, R. (1884). Klinische und anatomische Untersuchungen zur Lehre von den Bauchgeschwülsten und der Laparotomie. Arch. Gynäk., 24, 1י10-118.

Woodruff, R., and McDonald, J. R. (1940). Benign and malignant cystic tumors of the appendix. Surg. Gynec. Obstet., 71, 750755.

\section{Reports and Bulletins prepared by the Association of Clinical Biochemists}

The following reports and bulletins are published by the Association of Clinical Biochemists. They may be obtained from The Administrative Office, Association of Clinical Biochemists, 7 Warwick Court, Holborn, London, WC1R 5DP. The prices include postage, but air mail will be charged extra. Overseas readers should remit by British Postal or Money Order. If this is not possible the equivalent of 50p is the minimum amount that can be accepted.

\section{SCIENTIFIC REPORTS}

3 Automatic Dispensing Pipettes. An assessment of 35 commercial instruments 1967 P. M. G. BROUGHTON, A. H. GOWENLOCK, G. M. WIDDOWSON, and K. A. AHLQUST 80p (\$2)

4 An Evaluation of five Commercial Flame Photometers suitable for the Simultaneous Determination of Sodium and Potassium March 1970 P. M. G. BROUGHTON and J. B. DAWSON $80 \mathrm{p}(\$ 2)$

\section{SCIENTIFIC REVIEWS}

1 The Assessment of Thyroid Function March 1971 F. V. FLYNN and J. R. HOBBS $60 \mathrm{p}(\$ 1.50)$

2 Renal Function Tests Suitable for Clinical Practice January 1972 F. L. MITCHELL, N. VEALL, and R. W. E. WATTS $60 \mathrm{p}(\$ 1.50)$

\section{TECHNICAL BULLETINS}

9 Determination of Urea by AutoAnalyzer November 1966 RUTH M. HASLAM 40p (\$1)

11 Determination of Serum Albumin by AutoAnalyzer using Bromocresol Green October 1967 B. E. NORTHAM and G. M. WIDDOWSON 40p (\$1)

13 An Assessment of the Technicon Type II Sampler Unit March 1968 B. C. GRAY and G. K. MCGOWAN $40 \mathrm{p}(\$ 1)$

14 Atomic Absorption Spectroscopy. An outline of its principles and a guide to the selection of instruments May 1968 J. B. DAWSON and P. M. G. BROUGHTON $40 \mathrm{p}(\$ 1)$

15 A Guide to Automatic Pipettes (2nd edition) June 1968 P. M. G. BROUGHTON 40p (\$1)
16 A Guide to Automation in Clinical Chemistry May 1969 P. M. G. BROUGHTON 60p (\$1.50)

17 Flame Photometers (2nd edition) 1969 P. WILDINo $60 \mathrm{p}(\$ 1.50)$

18 Control Solutions for Clinical Biochemistry (4th edition) March 1970 P. M. G. BROUGHTON 60p (\$1.50)

19 Spectrophotometers. A comparative list of low-priced instruments readily available in Britain May 1970 C. E. WILDE and P. SEWELL 60p (\$1.50)

20 Quantities and Units in Clinical Biochemistry June 1970 P. M. G. BROUGHTON 60p (\$1.50) More than 30 copies in units of 10 at 20p

21 Filter Fluorimeters: A comparative list of 18 instruments September 1970 H. BRAUNSBERG and s. S. BROWN 60p (\$1.50)

22 Bilirubin standards and the Determination of Bilirubin by Manual and Technicon AutoAnalyzer Methods January 1971 BARBARA BILLING, RUTH HASLAM, and N. WALD 60p (\$1.50)

23 Interchangeable Cells for Spectrophotometers and Fluorimeters September 1971 E. S. BROWN and A. H. GOWENLOCK 60p (\$1.50)

24 Simple Tests to Detect Poisons March 1972 B. w. MEADE et al. $60 \mathrm{p}(\$ 1.50)$

25 Blood Gas Analysers May 1972 k. DIxoN 60p (\$1.50)

26 Kits for Enzyme Activity Determination September 1972 S. B. ROSALKI and D. TARLOW 80p $(\$ 2.00)$

27 Assessment of Pumps Suitable for Incorporation into Existing Continuous Flow Analytical Systems November 1972 A. FLECK et al 60p (\$1.50) 